\title{
Legal professional restrictions of medical professionals under the legislation of Ukraine: problems and prospects
}

\author{
0. H. Aleksieiev*A,D,F, M. A. Anishchenko ${ }^{B, C, E, F}$
}

Zaporizhzhia State Medical University, Ukraine

A - research concept and design; B - collection and/or assembly of data; C - data analysis and interpretation; D - writing the article; $\mathrm{E}$ - critical revision of the article; $\mathrm{F}$ - final approval of the article

Key words: professional misconduct, medical law.

Pathologia 2019; 16 (2), 288-292

DOI:

10.14739/2310-1237.

2019.2.177200

*E-mail:

agagroup@ukr.net

The aim: to conduct a system analysis of the complex of legislative restrictions in the professional activities of medical professionals from the standpoint of medical law, define the notion of "legal professional restrictions of medical workers", identify problems of legal regulation of these legal relations and outline the ways to resolve them.

Materials and methods. The research material is a modern regulatory framework. The methods of information retrieval, analysis, systematization and generalization were carried out.

Results. In accordance with the innovations of Article $78^{1}$ of the Fundamentals, from August 1, 2012, medical and pharmaceutical professionals began to be subject to legal restrictions on their professional activities. Simultaneously with the addition of the Fundamentals of the Legislation of Ukraine on Health Protection in Article $78^{1}$ of the Law of Ukraine, the Code of Ukraine on Administrative Offenses underwent corresponding changes. The introduction of restrictions is quite natural. Having entered into force, these provisions should increase the social responsibility of all participants in a legal relationship, and their main goal is to establish obstacles to possible abuse, create conditions for the independence of professional activity, and guarantee the patient's right to qualified medical care.

Conclusions. Legal professional restrictions of medical professionals represent the limitation of professional rights and duties of medical professionals, established by law in order to ensure public interests, prevent offenses, protect the rights and legitimate interests of medical professionals themselves.

Киючові слова: професійних норм порушення, медичне законодавство.

Патологія. - 2019. T. 16, № 2(46). C. 288-292

\section{Правові професійні обмеження медичних працівників згідно з законодавством України: проблеми та перспективи}

\section{О. Г. Алексєєв, М. А. Аніщенко}

Мета роботи - виконати системний аналіз із позицій медичного права комплексу законодавчих обмежень у професійній діяльності медичних працівників, дати визначення поняттю «правові професійні обмеження медичних працівників», виявити проблеми правового регулювання названих правовідносин та окреслити шляхи їх вирішення.

Матеріали та методи. Матеріал дослідження - сучасна нормативно-правова база. Використали методи інформаційного пошуку, аналізу, систематизації та узагальнення.

Результати. Відповідно до нововведень статті 781 Основ від 1 серпня 2012 року на медичних і фрармацевтичних працівників стали поширюватися визначені законом обмеження при здійсненні ними професійної діяльності. Одночасно з доповненням Основ законодавства України про охорону здоров'я в статті 78 ${ }^{1}$ Закону України відповідних змін зазнав і Кодекс України про адміністративні правопорушення. Введення обмежень цілком закономірне. Набравши чинності, такі положення повинні підвищити соціальну відповідальність усіх учасників правовідносин, а їхньою основною метою $€$ встановлення перешкод можливим зловживанням, створення умов для незалежності профресійної діяльності, гарантованості прав пацієнта на кваліфіковану медичну допомогу.

Висновки. Правові професійні обмеження медичних працівників є лімітуванням професійних прав, обов'язків медичних працівників, що встановлені законодавством для забезпечення публічних інтересів, запобігання правопорушенням, захисту прав і законних інтересів пацієнтів і самих медичних працівників.

Ключевые слова: профессиональных норм нарушения, медицинское законодательство.

Патология. - 2019. T. 16, № 2(46). C. 288-292

\section{Правовые профессиональные ограничения медицинских работников по законодательству Украины: проблемы и перспективы}

\section{А. Г. Алексеев, М. А. Анищенко}

Цель работы - провести системный анализ с позиций медицинского права комплекса законодательных ограничений в профессиональной деятельности медицинских работников, дать определение понятию «правовые профессиональные ограничения медицинских работников», выявить проблемы правового регулирования указанных правоотношений и очертить пути их разрешения.

Материалы и методы. Материал исследования - современная нормативно-правовая база. Использованы методы информационного поиска, анализа, систематизации и обобщения. 
Результаты. В соответствии с нововведениями статьи 78 Основ с 1 августа 2012 года на медицинских и фармацевтических работников стали распространяться определенные законом ограничения при осуществлении ими профессиональной деятельности. Одновременно с дополнением Основ законодательства Украины об охране здоровья в статье $78^{1}$ Закона Украины соответствующих изменений претерпел и Кодекс Украины об административных правонарушениях. Введение ограничений вполне закономерно. Вступив в силу, данные положения должны повысить социальную ответственность всех участников правоотношения, а их основной целью является установление препятствий возможным злоупотреблениям, создание условий для независимости профессиональной деятельности, гарантированности прав пациента на квалифицированную медицинскую помощь.

Выводы. Правовые профессиональные ограничения медицинских работников представляют собой лимитирование профессиональных прав и обязанностей медицинских работников, установленные законодательством для обеспечения публичных интересов, предупреждения правонарушений, защиты прав и законных интересов пациентов и самих медицинских работников.

The process of domestic medicine's reformation is characterized by more deep transformation of health care system, including the elaboration of new requirements to medical professional status. In his professional activity every doctor except established rights and duties, must remember about the number of restrictions imposed by the Law of Ukraine "Fundamentals of Health Care Legislation" (further - Fundamentals), and also by the other legal and regulatory instruments.

\section{The aim}

To conduct a system analysis of the complex of legislative restrictions in the professional activities of medical professionals from the standpoint of medical law, define the notion of "legal professional restrictions of medical workers", identify problems of legal regulation of these legal relations and outline the ways to resolve them.

\section{Materials and methods}

The research material is a modern regulatory framework. The methods of information retrieval, analysis, systematization and generalization were carried out.

\section{Results}

According to A. Denisova's (2011) statement legal restrictions are legal exclusions from legal human status which has preventive nature, protect the subjects whom these restrictions apply to and the other persons as well from unpleasant consequences [1].

According to A. Komzyuk's (2015) opinion, "restrictions" can be interpreted as follows: subjective right exists, but due to certain circumstances it can't be realized. The necessity of existing such restrictions is explained by the fact that there are cases of conflicts of individual and public interests [2].

Analysis of the legislation shows that restriction in the professional medical activity can be divided into two groups: restrictions of rights and restrictions of duties.

Studying the legislation that regulates medical activity we can highlight the following restrictions of medical professional's duties: restrictions of duty not to disclose medical confidentiality; restrictions of duty to provide free medical care by the program of state medical guarantees; restrictions of duty to provide full information about patient's health if it can worsen his health; restriction of the number of patients whom the doctor must make dec- laration with under state medical guarantees; restriction of duty to provide medical care to the emergency patient in case of ascertaining the biological death of a person.

Accordingly the following restrictions of the professional rights of medical professionals can be selected: restriction of the right to refuse patient in the case of non-compliance with the recommendations and internal labor regulations of health care facility if it won't threaten the patient's life and population's health; restriction of the right to free choice of the approved forms, methods and means of activity, according to established order introduction of modern achievements of medical and pharmaceutical science and practice by the state standards and clinical protocols, and also by the restrictions prescribed by Article $78^{1}$ of the Fundamentals [3].

Issues of legal restrictions of professional rights and duties of medical professional have a number of problem moments of legal regulation and ethical issues and also legal conflicts.

So restriction of duty not to disclose medical confidentiality is regulated by the number of laws and bylaws such as Civil Code of Ukraine, Code of Criminal Procedure of Ukraine, Code of Civil Procedure of Ukraine, Fundamentals, Laws of Ukraine "About Counteracting Tuberculosis", "AboutAnti-Drug, Psychotropic Substances and Precursor Trafficking Measures and Anti-Abuse" and others [4].

Restriction of duty to provide free medical care by the program of state medical guarantees doesn't comply with the current Constitution because it directly restricts constitutional right to free medical care in public and municipal health facilities, that is unacceptable according to the Article 22 of the Constitution of Ukraine [5].

Restriction of duty to provide full information about patient's health if it can worsen his health has a number of problems first of all problems of moral and ethical plan. Opponents of this restriction consider that everybody has the right to prepare for death (to complete the affairs, make death orders including legal ones), and silence of such information is, in their opinion, a violation of human rights to information. From the other side the law isn't clearly written who can provide full medical information about such patient as it must be objectively known to those people who take care of the patients.

Restriction of the patients' number according to the Order of realization of state medical guarantees of medical care due to the program of medical guarantees for the first aid in the year 2019, approved by the Resolution of Cabinet of Ministers of Ukraine on December 12, 2018, number 1117 , which the doctor must make declaration 
with under the medical guarantee program, comes into conflict with the article 34 of Fundamentals which clearly states that the doctor has the right to refuse in two cases: in case of non-compliance with the recommendations of the doctor and in case of non-compliance with the internal regulations of health care facility [6].

Restriction of duty to provide medical care to the emergency patient in case of ascertaining the biological death of a person entails a number of ethical problems connected with euthanasia and also realization of the right to dignified death movement for which has enough popularity in the countries of Western Europe and in Ukraine as well.

Restriction of the right to free choice of the approved forms, methods and means of activity, according to established order introduction of modern achievements of medical and pharmaceutical science and practice by the state standards and clinical protocols has also some problems as after the implementation of notion "new clinical protocol" into Ukrainian legislation and related ability to apply translations of foreign clinical protocols in medical practice is faced with frequent facts of inability to apply the latter because of inconsistency of methods of preparations and medical equipment.

In accordance with the innovations of Article $78^{1}$ of Fundamentals since August 1, 2012, medical and pharmaceutical professionals began to be the subject to legal restrictions on their professional activities [3].

1. Medical professionals aren't entitled to receive undue profits from business entities producing and/or selling medicines [3]. According to part 1 of article 1 of the Law of Ukraine "On Prevention of Corruption" unlawful benefits are cash or other property, advantages, privileges, services, intangible assets, any other benefits, any other non-material or non-monetary benefits that are promised, offered, provided or received without legal basis. This law contains the concept of a gift, which is defined as cash or other property, advantages, privileges, services, intangible assets, that are provided/received free of charge or at a price below the minimum market [7]. But the above definitions don't provide clear distinction between the concepts of "undue benefit" and "gift", and only with deeper study of legislation we understand that the main difference of undue benefit from gift is that the undue benefit is granted for the implementation of certain actions in favor of specific legal entities and/or individuals (in our case pharmaceutical companies, their professionals or individual entrepreneurs engaged in pharmaceutical business) and gift is based on a donation agreement (more often in written form rather than verbally) without conditions for performing any actions. Thus it turns out that doctors can receive gifts from the pharmaceutical business entities, but they can't cooperate, that is to carry out certain actions in favor of such subjects.

Exceptions are pedagogical or scientific activity, clinical contract remuneration for medical product or clinical trials of medical products and medical equipment.

If we are talking about the receiving of remuneration, it is necessary to have a documented agreement on the provision of reciprocal services subject to the following conditions:

- written form of the approval of the Agreement by the employer;
- proper documentation payouts;

- fair market value of services.

It is acceptable to compensate medical professional reasonable and documented expenses arising in the implementation of the above activities (for example, travel, accommodation, meals) under a paid agreement [8].

Parties are encouraged to sign the certificate of delivery and receipt of services, to save proof of expenses (tickets, vouchers, receipts).

Only those medical professionals who are teachers (that is they are in an employment relationship with the educational organization and perform the duties of training, educating and/or organizing educational activities) can be involved in the performance of educational services.

As for the educational activities they should correspond to a certain subject, for example, inform about a drug or medical device, cover and introduce scientific or educational information in the health care sector [9]. This could include master classes and the training of medical professionals in the installation and use of specific products in order to ensure their effective and safe use. These can be practical exercises using medical products or dummies, as well as lectures and presentations, information about medical technologies used by the company.

It should be stipulated that pharmaceutical companies can make donations to non-profit organizations under a donation agreement, as well as participate in charity and support independent educational activities of third parties.

Conference support may be provided in the form of grants to organizers, payment for the participants' food if the rules established by the conference organizers allow. At the same time, demonstration of products and services of companies at conferences is allowed. It is also allowed to sponsor satellite symposia, to present lecturers and materials for their holding.

2. Medical professionals don't have the right to receive from the business entities or their representatives engaged in the production and/or sale of medicines, medical products, samples of medicines, medical devices for use in professional activities (except for cases related to conducting clinical trials of medical products in accordance with the agreements) [3].

When conducting clinical trials of medicines or clinical trials of medical products, it is allowed to conclude agreements on their prescription or recommendation to patients; receive samples for delivery to patients, hold meetings with companies' representatives.

This restriction is aimed at making the objective decision of the doctor to use a medicine or medical product in the treatment. Such decision should be free from lobbing, public relations and direct bribing by the manufacturers of any medical products.

3. Medical professionals don't have the right to advertise medicines, medical products, including prescribe medicines on forms containing advertising information, and indicate the manufacturers of medicines (brands) [3].

According to the definition carried out in the Law of Ukraine "On Advertising", advertising is information about a person or product, distributed in any form and by any means and intended to form or maintain awareness of advertising consumers and their interest in such goods 
or persons. Consumers of advertising are considered to be an indefinite number of persons whom advertising is directed on [10].

It is recommended to organize promotional events in business centers, educational institutions, hotels and other places intended for business and educational events.

In the opinion of D. Pivnya and I. Kitsula (2016), in contrast to the above, information about medicine directed at a specific person (individualized information) and intended to provide medical care cannot be considered as advertising [9].

In our opinion, according to the Ukrainian legislation, the doctor may provide the patient with the international non-patented name of the medical product, and not its trade name.

But the use by physicians in their professional activity available for public viewing and viewing branded souvenirs (gowns, pens, calendars, posters, etc.) containing information about medicines and medical products (for example, the name) has certain risks, because can be attributed to the advertising of such products [8].

The question of restricting medical professionals to indicate the definition of the trade name of the drug is quite controversial, since there are quite a lot of pharmacological studies that prove the superiority of the original drugs over generics and their more serious therapeutic effect. So, the famous Ukrainian pharmacologist I. Zupanets (2014) believes that the genetic drug, compared with the original, has only one advantage $-a$ lower cost. However, this advantage loses its value when considering the effectiveness of such a drug and its safety. One of the main causes of this phenomenon can be low or high bioavailability compared with the original drug, as well as low stability and the presence of impurities that cause unanticipated side effects, which leads to lower effectiveness and safety of the generic drug. Only the availability of complete information on compliance with GMP standards in the production of generic, its pharmacokinetic and therapeutic equivalence when compared with the original drug makes it reasonable to search for the pharmacoeconomic benefits of the generic drug [11].

Simultaneously with the addition of the Fundamentals of the Legislation of Ukraine on Health Protection in Article $78^{1}$ of the Law of Ukraine on Administrative Offenses has undergone corresponding changes [3].

According to the newness in the Code of Ukraine on Administrative Offenses in Article $44^{2}$, violation of the restrictions established for medical professionals and pharmaceutical workers in the exercise of their professional activities, entails the imposition of a fine of 300 non-taxable minimum of income (5.100 hrn).

The same actions committed again during the year after the imposition of an administrative penalty entail the imposition of a fine of 1.200 non-taxable minimum of citizens' income (20.400 hrn) [12].

These measures are intended to promote respect for the rights and legitimate interests of both patients and physicians; they have a preventive function of preventing offenses.

Thus, by means of the restrictions prescribed in Article $78^{1}$ of the Fundamentals, the legislator established the legal framework for professional communication of medical professionals and pharmaceutical workers with representatives of organizations producing medicines and medical products.

The introduction of restrictions is quite natural. Coming into force these provisions should increase the social responsibility of all participants in the legal relationship, and their main goal is to establish obstacles to possible abuse, to create conditions for the independence of professional activity, and to guarantee a patient the rights to qualified medical care.

It is significant that the legislator hasn't introduced a total ban on communication of representatives of companies and medical professionals. The possibility of meeting with representatives of companies in order to conduct clinical research, improve their professional level and provide information on the monitoring of the safety of medicines and medical products, as well as financing the teaching and research activities of medical professionals has been allowed. Naturally, without the professional communication of the medical and pharmaceutical community, the development of medical science and, accordingly, improving the quality of treatment in the interests of patients isn't possible.

The important direction of legal work is the improvement of legal techniques of legislation governing medical activities, including such an important legal institution as the legal restrictions. As our study shows, this legal institution is regulated by more than ten regulatory legal acts, which creates an inconvenience in its study not only for medical professionals but also for professional lawyers as well. In our deep conviction, medical legislation should be clear, accessible and convenient for study, first of all, to medical professionals.

\section{Conclusions}

1. Legal professional restrictions of medical professionals are the limitation of professional rights and duties of medical professionals, established by law in order to ensure state interests, prevent offenses, protect the rights and legitimate interests of medical professionals themselves.

2. The above restrictions have a number of legal problems that are subject to elimination by making appropriate changes to the current legislation of Ukraine.

Prospects for further research. Therefore, in further studies it's necessary to study the methodology of systematization of medical legislation, including significantly improve the legal technique of presentation of the institution of legal professional restrictions of medical professionals.

Conflicts of interest: authors have no conflict of interest to declare. Конфлікт інтересів: віАсутній.

НаАійшла Ао редакції / Received: 22.03.2019

Після Аоопрацювання / Revised: 29.03.2019

Прийнято Ао Аруку / Accepted: 20.05.2019

Informations about authors:

Aleksieiev 0. H., PhD, Associate Professor of the Department

of Management and Pharmacy Economics, Medical and

Pharmaceutical Law, Zaporizhzhia State Medical University,

Ukraine. 
Anishchenko M. A., PhD, Associate Professor of the Department of Management and Pharmacy Economics, Medical and Pharmaceutical Law, Zaporizhzhia State Medical University, Ukraine.

\section{Відомості про авторів:}

Алексєєв О. Г., канА. фарм. наук, Аоцент каф. управління і економіки фармації, меАичного та фармацевтичного права, Запорізький державний медичний університет, Україна. Аніщенко М. А., канА. юриА. наук, доцент каф. управління і економіки фармації, меАичного та фармацевтичного права, Запорізький Аержавний меАичний університет, Україна.

\section{Сведения об авторах:}

Алексеев А. Г., канА. фарм. наук, Аоцент каф. управления и экономики фармации, медицинского и фармацевтического права, Запорожский государственный медицинский университет, Украина.

Анищенко М. А., канА. юриА. наук, Аоцент каф. управления и экономики фармации, медицинского и фармацевтического права, Запорожский государственный меАицинский университет, Украина.

\section{References}

[1] Denysova, A. M. (2011) Pravovi obmezhennia: poniattia, vydy, funktsi [Legal constraints: concepts, types, functions]. Chasopys Kyivskoho universytetu prava, 2, 51-55. [in Ukrainian].

[2] Komziuk, M. A. (2015) Poniattia, zmist, vydy ta formy obmezhennia osobistoi svobody hromadian za administratyvnym pravom [Concept, content, types and forms of restriction of personal freedom of citizens under administrative law]. Yevropeiski perspektyvy, 1, 52-58. [in Ukrainian]

[3] Zakon Ukrainy «Osnovy zakonodavstva Ukrainy pro okhoronu zdorovia» vid 19.11.1992 №2801-XII [Law of Ukraine «Fundamentals of Ukrainian Health Care Legislation» from November 19, 1992 №2801XII]. Retrieved from https://zakon.rada.gov.ua/laws/show/2801-12/ ed20140802 [in Ukrainian].

[4] Dichko, H. O. (2019) Vypadky pravomirnoho Rozkryttia medychnoi taiemnytsi [Cases of lawful disclosure of medical secrets]. Pravovi problemy suchasnoi transformatsii okhorony zdorovia. Proceedings of the International Scientific and Praktical Conference, (p. 57-60). [in Ukrainian].

[5] Konstytutsiia Ukrainy: Osnovnyi Zakon vid 28.06.1996 №254k/96VR [The Constitution of Ukraine: Basic Law of June 28, 1996. №254k/96-VR.] Retrieved from https://zakon.rada.gov.ua/laws/ card/254\%D0\%BA/96-\%D0\%B2\%D1\%80. [in Ukrainian].

[6] Poriadok realizatsii derzhavnykh harantii medychnoho obsluhovuvannia naselennia za prohramoiu medychnykh harantii dlia pervynnoi medychnoi dopomohy na 2019 rik: zatverdzhenykh postanovoiu KMU vid 18.12.2018 №1117 [The procedure for the implementation of state guarantees for medical care of the population under the program of medical guarantees for primary health care in 2019, approved by the Cabinet of Ministers of Ukraine from December 12, 2018 №1117]. Retrieved from https://zakon rada.gov.uallaws/show/1117-2018-\%D0\%BF. [in Ukrainian].

[7] Zakon Ukrainy «Pro zapobihannia koruptsii» vid 14.10.2014. №1700VII [The Law of Ukraine «On Preventing Corruption» from October 14, 2014. №1700-VII] Retrieved from https://zakon.rada.gov.ua/laws/ show/1700-18. [in Ukrainian].

[8] Kolyado, E. V., Lazarev, V. S., \& Perfilyev, A. A. (2013) Zakonodavchi obmezhennia, shcho nakladaiutsia na medychnykh i farmatsevtychnykh pratsivnykiv pid chas zdiisnennia nymy profesiinoi diialnosti [Legislative restrictions imposed on medical and pharmaceutical employees in realization of their professional activities]. Sibirskij medicinskij zhurnal, 122(7), 147-148. [in Russian].

[9] Piven, D. V., \& Kitsul I. S. (2016) Obmezhennia, shcho nakladaiutsia na medychnykh pratsivnykiv pid chas zdiisnennia profesiinoi diialnosti, izapobihannia konfliktu interesiv medychnoho pratsivnyka: dii medychnoi orhanizatsii [Restrictions on medical stuff in the exercise of professional activity and the prevention of conflicts of their interests: medical organization actions]. Menedzher zdravoohraneniya, 4,63. [in Russian].

[10] Zakon Ukrainy «Pro reklamu» vid 03.07.1996. №270/96-VR [Law of Ukraine «About advertising» from July 3, 1996. №270/96-VR]. Retrieved from https://zakon2.rada.gov.ua/laws/show/270/96$\%$ D0\%B2\%D1\%80 [in Ukrainian].

[11] Borovyk, S. P. (2014) Original'nye i genericheskie preparaty: mify i real'nost' [Original and generic drugs: myths and reality]. Ukrayinskyi medychnyi chasopys. Retrieved from https://www.umj.com.ual article/81906/originalnye-i-genericheskie-preparaty-mify-i-realnost [in Russian].
[12] Kodeks Ukrainy pro administratyvni pravoporushennia vid 04.12.1984 №8073-X [Code of Ukraine on Administrative Offenses from December 4,1984. №8073-X]. Retrieved from https://zakon.rada.gov.ua/laws/ show/80732-10. [in Ukrainian] 